\author{
Шевців Л.Ю., Курій І.Я.
}

\title{
ДОСЛІДЖЕННЯ СУЧАСНИХ АСПЕКТІВ ОБЛІКУ І АНАЛІЗУ РОЗРАХУНКІВ 3 ОПЛАТИ ПРАЦІ В УМОВАХ СТАЛОГО РОЗВИТКУ
}

\begin{abstract}
У статті досліджено динаміку $і$ темпи зростання мінімальної заробітної плати, прожиткового мінімуму в Україні. Проаналізовано стан оплати прачі на вітчизняних підприємствах, досліджено купівельну спроможність заробітної плати. На основі підприємства показано рівень заробітної плати $в$ нашій країні. Визначено негативні тенденції в оплаті праці. З'ясовано причини низького рівня заробітної плати. Розглянуто особливості впливу розміру заробітної плати на сталий розвиток краӥни. Визначені шляхи вирімення проблем заробітної плати в нашій державі.
\end{abstract}

Ключові слова: облік, аналіз, середня і мінімальна заробітна плата, сталий розвиток, прожитковий мінімум, нарахування заробітної плати.

Постановка проблеми. Процеси інтеграції в світову економічну спільноту потребують удосконалення соціального захисту працюючих, якісних механізмів поповнення соціальних фондів. Відсутність системного підходу щодо обліку виплат працівникам впливає на систему бухгалтерського обліку будь-якого підприємства. Вплив негативних чинників соціальноекономічного розвитку в Україні, ігнорування норм законодавства щодо оплати праці, низький iii рівень, зменшення грошових винагород та ін. чинники не сприяють зростанню продуктивності та ефективності праці, впливають на інвестиційну активність. Облік оплати праці на підприємстві потребує точних i оперативних даних, щодо зміни чисельності робітників, витрат робочого часу, виробничих витрат. Зокрема «цілі забезпечення сталого розвитку передбачають до 2030 року поступове наближення мінімального рівня заробітної плати та мінімальної пенсії не нижче фактичного прожиткового мінімуму, до 2020 року визначати мінімальну вартість години найманої праці для підприємств усіх форм власності. Пріоритетом політики сталого розвитку є забезпечення гідних умов життя та праці у власній країні» [1]. Тому, особливого значення набуває вивчення зарубіжного досвіду, ведення обліку і аналіз розрахунків 3 оплати праці вітчизняних підприємств, формування пропозицій щодо удосконалення в контексті загальних проблем економіки.

(C) Шевців Любов Юліанівна, к.е.н., доц., доцент кафедри обліку i аудиту факультету управління фінансами та бізнесу, ЛНУ ім. Івана Франка, м.Львів, тел.: 0674747691, email: shevtsivlyba@gmail.com Курій Ірина Ярославівна, магістр кафедри обліку і аудиту факультету управління фінансами та бізнесу, ЛНУ ім. Івана Франка, м.Львів, тел.: 0507476018, email: iradatc94@gmail.com
Аналіз останніх досліджень і публікацій. Окремі питання обліку i аналізу праці i заробітної плати підприємств досліджували вітчизняні та зарубіжні вчені а саме: Білуха М.Т., Бутинець Ф.Ф., Івахненко В.М., Малюга Н.М., Мних Є.В., Тарасенко Н.В., Череп А.В., Чумаченко М.Г. та інші.

Проте ряд питань, що стосуються розкриття позитивних i негативних наслідків для населення, так і для економіки країни загалом, аналіз соціальних стандартів України протягом 2015-2017 рр., зокрема розрахунків 3 оплати праці та визначення місця країни у європейському просторі щодо забезпечення добробуту громадян потребує подальшого дослідження.

Формулювання цілей статті. Метою статті $\epsilon$ дослідження: правильності та обгрунтованості використання фонду оплати праці комунальних підприємств, аналізування залежності оплати праці від рівня законодавчо встановленої мінімальної заробітної плати та прожиткового мінімуму, встановлення причин відхилень від плану, i розробка напрямів подальшого удосконалення використання фонду оплати праці в сучасних кризових умовах. Для досягнення поставленої в дослідженні мети використано загальнонаукові та спеціальні методи і прийоми наукового дослідження: узагальнення; групування; аналізу, порівняння, систематизації.

Опис основного матеріалу дослідження. В умовах економічної трансформації державне регулювання оплати праці визначається фінансовими можливостями країни, в тому числі прямими і непрямими методами (встановлення розміру мінімальної заробітної плати) та відповідно нормативно-правових актів 3 оплати праці. Саме заробітна плата є і повинна бути головною складовою доходів населення, підгрунтям життєдіяльності працівників та їх сімей, а звідси 
й найбільш потужним стимулом підвищення продуктивності праці. Заробітна плата це винагорода, обчислена, як правило, у грошовому виразі, яку за трудовим договором роботодавець виплачує працівникові за виконану ним роботу [2]. Із-за різкого зростання вторинної зайнятості, яка досягла 50-60\%, держава практично відмовилась від регулювання заробітної плати у бюджетному секторі [3]. 31 січня 2017 р. в Україні змінилося значення самого терміну «мінімальна зарплата». Зокрема державна гарантія для працівників стосується не тільки розміру окладу, а й заробітної плати працівника за місяць в цілому. Таким чином, роботодавець зобов'язаний буде щомісяця виплачувати працівнику за повний відпрацьований місящь заробітну плату у мінімальному розмірі, яка може складатися 3: окладу, премій, надбавок та інших постійних доплат (окрім доплати за роботу в несприятливих умовах праці та підвищеного ризику для здоров'я за роботу в нічний та надурочний час, роз'їзний характер робіт, премії до святкових і ювілейних дат) [2].

Так, мінімальна заробітна плата в місяць в Україні 31 січня 2015 складала 1218 грн, 3 1вересня 2015 - 1378 грн., 31 січня 2016 р. становила 1378 грн, 31 травня 2016 р. - 1450 грн, 31 грудня - 1600 грн. Відповідно в 2017 році мінімальна заробітна плата в місяць складала на 1 січня 3200 грн. В Україні на сьогодні (з 01.01.18p.) мінімальна заробітна плата становить 3723 грн (близько 3000 грн. на руки), відповідно Закону України від 7.12.2017p. №2246-VIII «Про Державний бюджет України на 2018p.». Для порівняння розмір мінімальної заробітної плати в Польщі в 2015 р. становив 1750 злотих, у 2016 р. 1850 злотих, 2017 р. - 2000 злотих, з 2018p. 2100 злотих. Зарплата нетто, тобто та, яку працівник отримає на руки після вирахування обов'язкових виплат (податок, медичне, соціальне, пенсійне страхування) складає близько 1530 злотих (близько 12133 грн) [4].

Для порівняння розглянемо розмір мінімальної заробітної плати європейських країн. Так він становив у 2017 році (в доларах): Чехія $550 \$$; Болгарія 309,52\$; Румунія 516,22\$; Греція $811,96 \$$; Іспанія 980,46\$; Польща 586,50\$; Німеччина 1778,8\$; Словаччина 575,93\$; Словенія - 955,89\$; Сербія - 225,51\$; Угорщина 537\$; Хорватія 524,52\$; Чорногорія 229,18\$; а також Бельгія 1819,17\$. Відповідно мінімальна заробітна плата в 2017 році у Великій Британії становила 1569 \$; Франція 1757,82\$; США 7,25\$ на 1 годину тоді як в Україні цей показник становив 125,21\$, в Росії 132,63\$, Білорусії $309,52 \$[4]$.
Однак зростання доходів не супроводжувалося реальним збільшенням ефективності праці. Незалежно від форми власності, облік і аналіз праці й заробітної плати займає важливе місце у системі обліку підприємства. Чітка організація і управління на основі обліково-аналітичної інформації передбачає виконання завдань обліку праці та іiі оплати [5]:

1) контроль за дотриманням штатної дисципліни та раціональним використанням робочого часу;

2) правильне обчислення витрат робочого часу та облік праці;

3) правильне обчислення заробітної плати та утримання з неї;

4) здійснення своєчасних i достовірних розрахунків по заробітній платі;

5) контроль за використанням фонду заробітної плати;

6) забезпечення споживачів інформацією про працю і заробітну плату.

Зокрема, відображається правильна організація обліку особового складу працівників, зміна чисельності працівників, витрати робочого часу, категорії працівників, виробничі витрати, використання фонду оплати праці порівняно 3 виконанням планових завдань, відносна економія або перевитрати, причини відхилень від плану, оцінка доцільності та ефективності запровадженої системи матеріального стимулювання.

Дослідження обліково-аналітичної діяльності проводилось на підприємстві ЛКП «Львівелектротранс» за результатами якого рекомендовано методичні підходи до обліку та аналізу праці і заробітної плати (див. табл. 1). ЛКП «Львівелектротранс» міський монополіст у сфері пасажирських перевезень електротранспортом Львова, що перебуває у власності громади міста Львова. Основним видом діяльності $€$ : надання послуг 3 перевезення населення електротранспортом; організація руху транспорту; визначення потреб населення для здійснення перевезень та потреби у рухомому складі; будівництво, експлуатація, технічне обслуговування і ремонт: трамвайних колій i колійних споруд; споруд та електрообладнання тягових підстанцій; систем телеуправління; електромереж; споруд та устаткування сигналізації та зв'язку; будівель і споруд підприємств. Підприємство здійснює облік оплати праці значного штату (більше тисячі осіб) за різними системами i формами, 3 різноманітними методами преміювання, стимулювання праці, компенсацій і доплат. 
Таблиця 1

Методичні підходи до обліку і аналізу праці та заробітної плати*

\begin{tabular}{|c|c|c|c|}
\hline $\begin{array}{c}\text { Види обліково- } \\
\text { аналітичної } \\
\text { діяльності }\end{array}$ & Мета дослідження & Методи дослідження & Носії інформації \\
\hline Облік & $\begin{array}{l}\text { організація } \\
\text { документообігу відповідно } \\
\text { до змін законодавчо- } \\
\text { нормативних документів і } \\
\text { порядку нарахування і } \\
\text { виплати заробітної плати }\end{array}$ & $\begin{array}{l}\text { методи узагальнення даних; } \\
\text { групування абстрактно-логічний } \\
\text { метод; метод причинно- } \\
\text { наслідкового зв'язку, метод } \\
\text { аналогії, діалектичний метод, } \\
\text { системний підхід, інформаційні } \\
\text { технології }\end{array}$ & $\begin{array}{lr}\text { Відомість } & \text { обліку } \\
\text { працівників підрозділу. } \\
\text { Штатний } \\
\text { табель розпис. } \\
\text { відпрацьованого } \\
\text { робочого часу; наряд } \\
\text { на відрядну роботу; }\end{array}$ \\
\hline Аналіз & $\begin{array}{ll}\text { обгрунтування } & \text { витрат } \\
\text { підприємства } & \text { на оплату } \\
\text { праці; } & \text { відповідність } \\
\text { оплати } & \text { праці } \\
\text { продуктивністю праці }\end{array}$ & $\begin{array}{l}\text { методи індукції, дедукції, теорії } \\
\text { економічного аналізу; метод } \\
\text { порівняння і узагальнення даних; } \\
\text { методи статистики (факторного } \\
\text { аналізу), системний підхід; } \\
\text { інформаційні технології }\end{array}$ & $\begin{array}{l}\text { маршрутний лист; } \\
\text { розрахунково-платіжна } \\
\text { відомість працівника; } \\
\text { зведена розрахунково- } \\
\text { платіжна відомість; } \\
\text { звіт з праці. }\end{array}$ \\
\hline
\end{tabular}

* Розроблено авторами за джерелом [3,5]

Для кращого розуміння існуючих проблем, пов'язаних із заробітною платою в Україні, доцільно розглянути рівень середньої заробітної плати на основі діяльності підприємства. 3 цією метою проведено аналіз заробітної плати на ЛКП
«Львівелектротранс» за 2015-2017 рр. (див.рис. 1).

Аналізуючи рис. 1, можна відмітити, що середня заробітна плата на підприємстві протягом 3 років мала тенденцію до зростання.

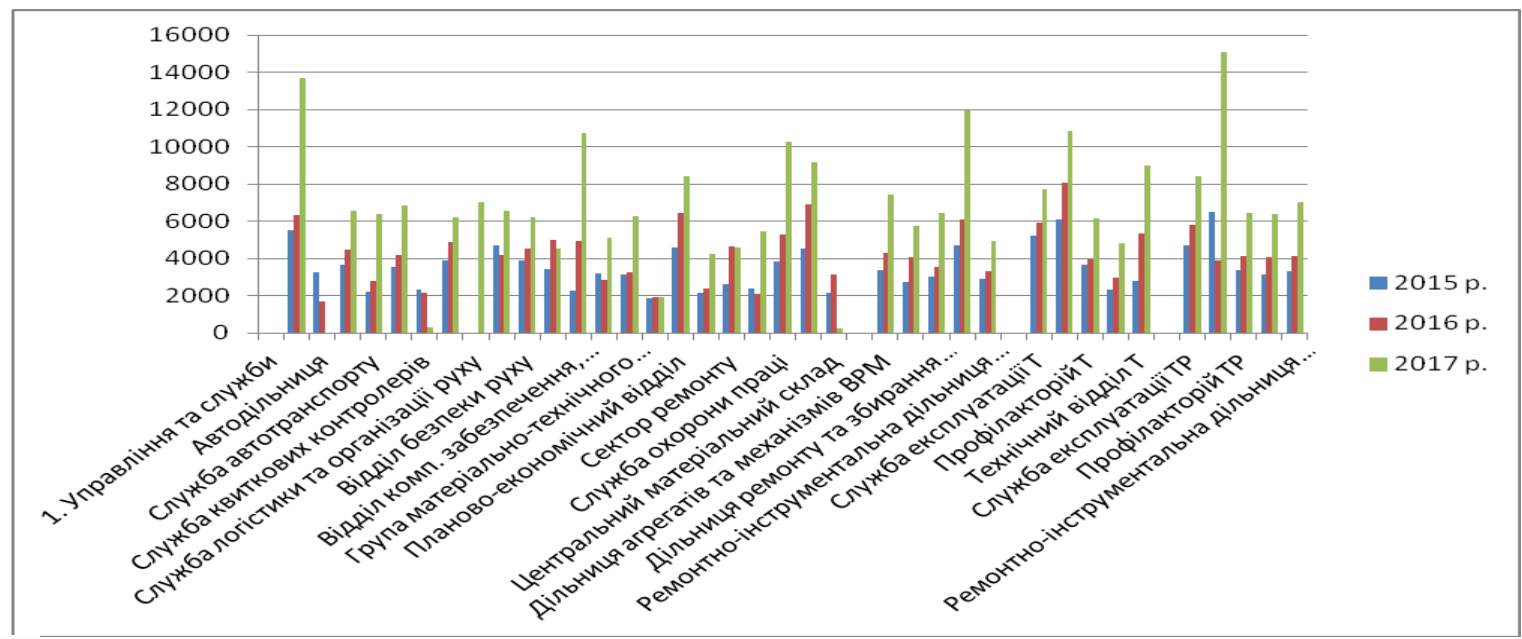

Рис. 1. Нарахування середньої заробітної плати на ЛКП «Львівелектротранс» за 2015-2017pp. *

* Розроблено авторами за джерелом [6]

Під час нарахування заробітної плати на підприємстві керуються Законом України «Про оплату праці» від 24.03.1995р. № 108/95-ВР, Постановою КМУ «Про затвердження обчислення Порядку середньої заробітної плати» від 8 лютого 1995 р. № 100 та окремими статтями Кодексу законів про працю. Підставою для нарахування заробітної плати на підприємстві $€$ табель обліку робочого часу. Облік відпрацьованого часу ведеться в годинах або в днях. Винагорода за працю складається 3 основної і додаткової заробітної плати та інших заохочувальних та компенсаційних виплат. Враховуючи зазначене, проаналізовано щомісячні нарахування заробітної плати працівникам ЛКП «Львівелектротрансу» за 2015-2017 роки (див.табл.2). 3 наведеної табл. 2 видно, що основну частину щомісячного доходу більшості працівників підприємства складають не посадовий оклад, а доплати, надбавки та премії, що виплачуються понад оклад.

Серед нарахувань також видно компенсацію у зв'язку з порушенням строків виплати зарплати. Якщо підприємство все-таки не дотрималось строків виплати заробітної плати та заборгувало працівникам зарплату, на підставі вимог ст. 3-4 Закону України «Про оплату праці» воно зобов'язане компенсувати працівникам втрату частини зарплати у зв'язку з порушенням строків іiї виплати. 
Таблиця 2

Нарахування заробітної плати у місяць працівникам ЛКП «Львівелектротранс» 3a 2015-2017 p.p. *

\begin{tabular}{|l|c|c|c|}
\hline \multicolumn{1}{|c|}{ Одні з найбільших нарахувань заробітної плати } & $\begin{array}{c}2015, \% \text { до } \\
\text { загального } \\
\text { ФОП }\end{array}$ & $\begin{array}{c}2016, \% \text { до } \\
\text { загального } \\
\text { ФОП }\end{array}$ & $\begin{array}{c}2017, \% \text { дог } \\
\text { загального } \\
\text { ФОП }\end{array}$ \\
\hline Оклад по годинах & 14,66 & 14,55 & 18,82 \\
\hline Доплата за реалізацію талонів & 8,19 & 7,18 & 6,12 \\
\hline Оплата за погодинними тарифними ставками & 28,86 & 27,56 & 26,78 \\
\hline Доплата за роботу в надурочний час & 0,02 & 1,05 & 1,72 \\
\hline Надбавка за класність & 7,57 & 3,57 & 3,91 \\
\hline Оплата по виробничих нарядах & 0,02 & 6,88 & 6,93 \\
\hline Оплата за відрядними розцінками & 0,73 & 0,19 & 0,43 \\
\hline Оплата за роботу в надурочний час & 0,0009 & 1,05 & 1,71 \\
\hline Оплата за роботу у святкові і неробочі дні & 0,0007 & 1,04 & 1,44 \\
\hline Оплата лікарняних листків (перші 5 днів) & 0,001 & 1,51 & 1,24 \\
\hline Доплата за роботу у святкові і неробочі дні & 0,0002 & 1,44 & 1,98 \\
\hline Доплата за роботу у вечірній час & 2,97 & 1,26 & 1,25 \\
\hline Доплата за роботу в нічний час & 0,08 & 1,66 & 1,83 \\
\hline Оплата лікарняних листків (соц. страх) & 0,91 & 2,81 & 2,62 \\
\hline Оплата по середньому заробітку (відрядження, донорство, курси & 0 & 0,97 & 0,57 \\
\hline ЦО і ін.) & 0 & 6,63 & 6,34 \\
\hline Оплата відпустки & 11,06 & 5,73 & 0,11 \\
\hline Індексація заробітної плати & 0,05 & 0,03 & 0 \\
\hline Компенсація в зв'язку з порушенням строків виплати зарплати & 0,93 & 0,12 \\
\hline Доплата ( різниця в окладах) & 0,0002 & 0,20 & 0,12 \\
\hline
\end{tabular}

*Розраховано авторами за звітністю ЛКП «Львівелектротранс за 2015-2017 p.

Компенсація проводиться 3 урахуванням індексу зростання цін на споживчі товари i тарифів на послуги у порядку, встановленому чинним законодавством. Порушення строків виплати працівникам на ЛКП «Львівелектротранс» пов'язано із невчасним надходженням коштів із міського бюджету Львова на рахунок підприємства. Проведений аналіз (див. табл.2) свідчить, що спостерігалась тенденція до зниження компенсації за порушення строків виплати зарплати, і у 2017 p. становила - 0 грн. Це свідчить про своєчасну виплату заробітної плати.
Також 3 нарахованої заробітної плати найманого працівника до бюджету утримується військовий збір, у 2015-2017 рр. в розмірі 1,5\% від нарахованої заробітної плати за усіма видами нарахувань. Виняток становить допомога по вагітності та пологах, 3 якої військовий збір не утримується. Нарахований єдиний соціальний внесок у 2015 році складав $36,8 \%$, а в 2017 році - 22\%. Також незалежно від суми нарахованої заробітної плати застосовувалася єдина ставка ПДФО. У 2015 році розмір становив 15\%, а в 2016-2017 pp. $18 \%$ [7].

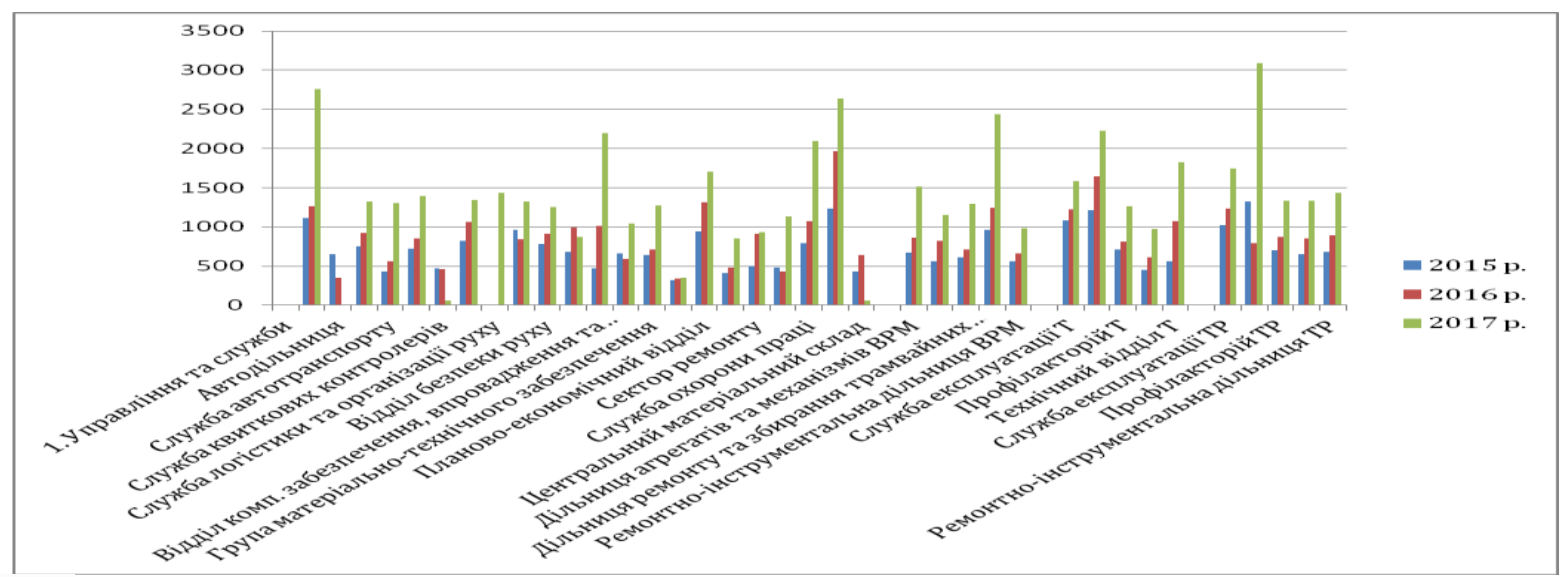

Рис. 2. Розмір середньомісячних утримань із заробітної плати на ЛКП «Львівелектротранс» за 2015-2017 роки*

*Розроблено авторами 


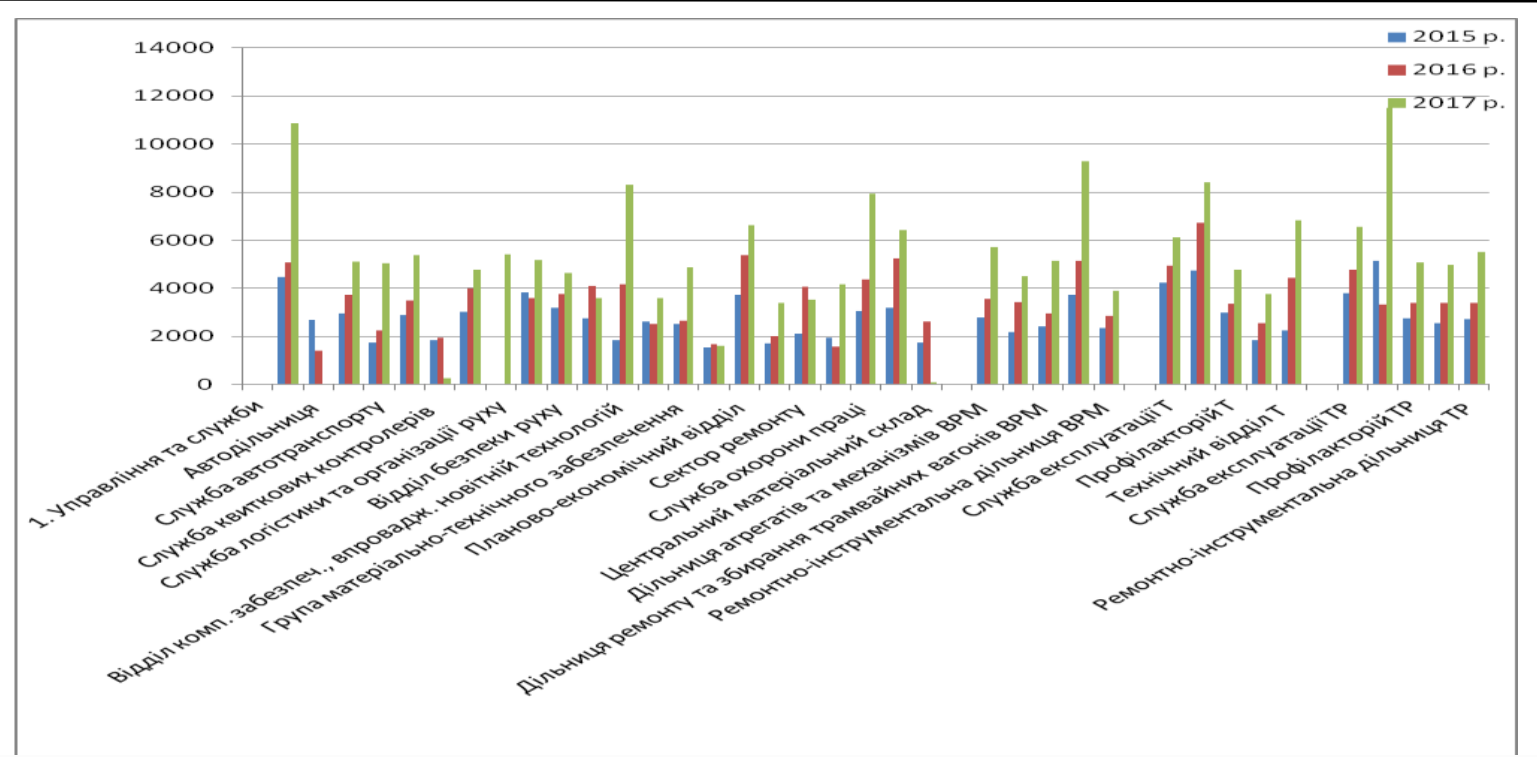

Рис. 3. Нарахування середньомісячних виплат працівнику на ЛКП «Львівелектротранс» за 2015-2017p.p.*

*Розроблено авторами

Враховуючи дані фінансової звітності та обліково-аналітичні дані ЛКП «Львівелектротрансу» за 2015-2017 р. на рис. 2 проаналізовано розмір середньомісячних утримань із заробітної плати.

Із вище наведених даних можна дослідити яку заробітну плату працівник отримує «на руки»: нарахована заробітна плата за мінусом утримань із неї (див.рис.3).

Наведене вище доводить, що заробітна плата на ЛКП «Львівелектротранс» залежить від прожиткового мінімуму. На рис. 3 видно як збільшувалася заробітна плата протягом 2015$2017 \mathrm{pp}$. внаслідок підвищення прожиткового мінімуму. Динаміку зміни мінімальної заробітної плати та прожиткового мінімуму в Україні в 2015-2017 р. подано на рис.4. 3 проведеного дослідження випливає, що заробітна плата на ЛКП «Львівелектротранс» цілком залежить від розміру прожиткового мінімуму у нашій країні, який на сьогодні $є$ одним із найнижчих у країнах Європи.

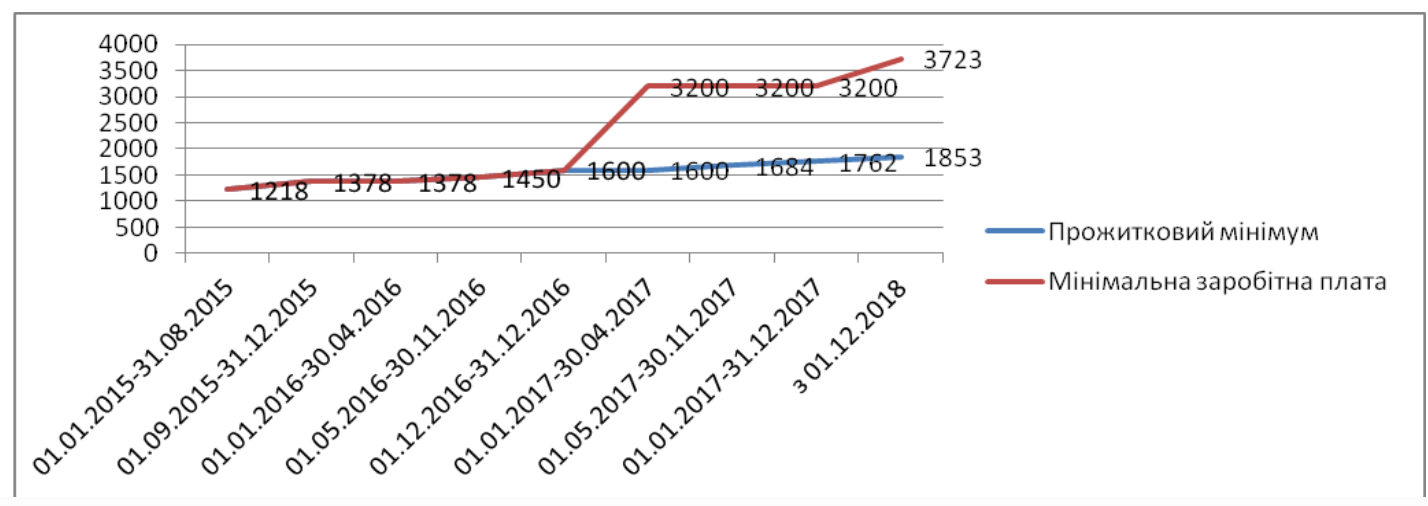

\section{Рис.4 Динаміка зміни мінімальної заробітної плати та прожиткового мінімуму в Україні в 2015-2017 p.p.: побудовано автором на основі [3]}

Занижена заробітна плата призвела сьогодні до скорочення вкрай необхідного для економіки держави попиту і визначила загальний рівень впевненості суспільства в майбутньому. Одним із пріоритетних завдань держави повинно стати стимулювання внутрішнього споживання та підвищення купівельної спроможності населення. До того ж, лише справедливий розподіл доходів у реальному секторі економіки допоможе подолати бідність в Україні.
Дослідження підтверджують, що на зарубіжних підприємствах (в організаціях) в більшості випадків впроваджена почасова, почасова 3 колективним та індивідуальним преміюванням оплата праці, якою охоплено більшість працівників, в Бельгії - 92,6 \%; Німеччини - 86,7 \%; Італії - 88,4 \%; Нідерландах $94,8 \%$; Франції - 93,5 \% [8]. Кожна галузь економіки формує власні тарифні сітки, які, у свою чергу, модифікуються на рівні компаній. 
Наприклад, в італійських компаніях використовується 20-розрядна тарифна сітка, а в американській автомобільній корпорації 23розрядна. В японських фірмах традиційно основна ставка визначається з урахуванням віку і стажу, а так звана трудова ставка - залежно від кваліфікації і результативності праці. Для італійських компаній характерна роздрібненість системи матеріального стимулювання, що відрізняє іï від інших систем, але має спільні риси з системою матеріального стимулювання в Україні, яка теж характеризується наявністю галузевих угод, 8-ми розрядних тарифних сіток, $\mathrm{i}$ тому не містить нового підходу до управління матеріальним стимулюванням [8].

Можливості адаптації вітчизняної економіки та використання зарубіжного досвіду сприятиме вдосконаленню системи стимулюванню оплати праці, формування i застосування багатоаспектної системи матеріального заохочення персоналу.

Висновки i перспективи подальших досліджень. Оскільки рівень оплати праці є показником добробуту населення, тому необхідно:
- подальше реформування оплати праці здійснювати за рахунок підвищення ціни робочої сили; збільшення тарифної частини у заробітній платі; підвищення частки мінімальної заробітної плати у середній заробітній платі, удосконалення механізму державно-договірного регулювання заробітної плати;

- ефективний облік і організація заробітної плати мають здійснюватися в поєднанні із загальною соціально-економічною, податковою та ціновою політиками;

- заходи, спрямовані на удосконалення оплати праці, включають забезпечення залежності розмірів заробітної плати від особистого внеску працівників у результати праці.

Вивчення зарубіжного досвіду та адаптація його до умов функціонування вітчизняних підприємств сприятиме подальшим дослідженням впровадженню ефективного механізму формування фонду оплати праці, забезпечення своєчасної виплати заробітної плати та іiі відповідний рівень в умовах формування сталого розвитку в Україні.

\section{ПЕРЕЛІК ВИКОРИСТАНИХ ДЖЕРЕЛ}

1. ПРОЕКТ Версія 3.4 станом на 29.12.2016 Стратегія сталого розвитку України на період до 2030 року.

2. Закон України “Про оплату праці" від 24. 03. 1995 р. № 108/95-ВР із змінами, внесеними законом від № 1774-VIII від 06.12.2016: [Електронний ресурс]. - Режим доступу: http://zakon2.rada.gov.ua/laws/show/108/95вp

3. Мардус Н. Ю. Методичні підходи до обліку, аудиту та аналізу праці і заробітної плати на підприємстві / Н. Ю. Мардус // Вісник ЖНАЕУ Фінанси, облік та аналіз господарської діяльності. - 2016. - № 1(54) Т.2. С.230-236.

4. Мінімальна заробітна плата: [Електронний ресурс]. - Режим доступу: https://index.minfin.com.ua/ua/labour/salary/min.

5. Морозюк Н. С. Актуальні питання заробітної плати в бюджетній сфері / Н.С. Морозюк // Фінанси, облік, банки. - 2014. - № 1 (20). С.203-208.

6. Середня заробітна плата по Україні: [Електронний ресурс]. - Режим доступу: http://index.minfin.com.ua/index/average.

7. Українські новини: [Електронний ресурс]. - Режим доступу: http://ukranews.com/ua/news/405273minimalna-zarplata-ukrainciv-vpala-zi-14854-do-5742-dolariv.

8. Баранов В.В. Світовий досвід побудови ефективної системи оплати праці на підприємстві / В.В. Баранов // Кіровоградський національний технічний університет. Економічні науки. - 2011. - Вип. 20, ч. I. С.139 - 145.

\section{REFERENCES}

1. Stratehiya staloho rozvytku Ukrayiny na period do 2030 roku (2016). [Strategy for sustainable development of Ukraine for the period up to 2030]. Proekt Versiya 3.4 [in Ukrainian].

2. Zakon Ukrayiny "Pro oplatu pratsi” vid 24. 03. 1995 r. № 108/95-VR iz zminamy, vnesenymy zakonom vid № 1774-VIII vid 06.12.2016 [Law of Ukraine “On wages and salaries” from March, 24 1995 № 108/95-VR]. Retrieved from: http://zakon2.rada.gov.ua/laws/show/108/95-vr [in Ukrainian].

3. Mardus, N.Yu. (2016). Metodychni pidkhody do obliku, audytu ta analizu pratsi i zarobitnoyi platy na pidpryyemstvi [Methodical approaches to accounting, auditing and analysis of labor and wages at an enterprise]. Visnyk ZHNAEU, Finansy, oblik ta analiz hospodars'koyi diyal'nosti - Bulletin ZHNAEU, Finance, accounting and analysis of economic activity, 1(54), 230-236 [in Ukrainian].

$\begin{array}{llllll}\text { 4. Minimal'na zarobitna plata [Minimum } & \text { wage] } & \text { (n.d.). Retrieved from:: }\end{array}$ https://index.minfin.com.ua/ua/labour/salary/min. [in Ukrainian].

5. Morozyuk, N.S. (2014). Aktual'ni pytannya zarobitnoyi platy v byudzhetniy sferi [Topical issues of wages in the budget sphere]. Finansy, oblik, banky - Finance, accounting, banks, 1 (20), 203-208 [in Ukrainian]. 
6. Serednya zarobitna plata po Ukrayini: [Average wages in Ukraine] (n.d.). Retrieved from: http://index.minfin.com.ua/index/average [in Ukrainian].

7. Ukrayins'ki novyny [Ukrainian News] (n.d.). Retrieved from::http://ukranews.com/ua/news/405273-minimalnazarplata-ukrainciv-vpala-zi-14854-do-5742-dolariv [in Ukrainian].

8. Baranov, V.V. (2011). Svitovyy dosvid pobudovy efektyvnoyi systemy oplaty pratsi na pidpryyemstvi [World experience of building an effective system of remuneration in an enterprise]. Kirovohrads'kyy natsional'nyy tekhnichnyy universytet. Ekonomichni nauky - irovohrad National Technical University. Economic sciences, 20, 139 145 [in Ukrainian].

Одержано 05.03.2018 p. 